\title{
TOURISM, BRANDING AND TERRITORIAL IDENTITY IN THE RURAL SPACE. LOCAL AUTHORITIES' PERSPECTIVE
}

\author{
Bianca Sorina RĂCĂŞAN \\ Babeş-Bolyai University, Cluj-Napoca, Faculty of Geography, Department of Human Geography and Tourism, ROMANIA \\ bianca.racasan@geografie.ubbcluj.ro
}

\section{István EGRESI}

Babeş-Bolyai University, Cluj-Napoca, Faculty of Geography, Department of Human Geography and Tourism, ROMANIA istvan.egresi@geografie.ubbcluj.ro

DOI: http://doi.org/10.23740/TID220192

\section{ABSTRACT}

While diversification as an economic strategy could be the solution to territorial development, concepts such as specialisation, individualisation and uniqueness should always be kept in mind in the branding process of any destination. The purpose of this study was to identify to what extent did local authorities understand these principles and what sort of brand elements they considered to be suitable for the administrated commune, in the context of a certain territorial identity that tourism could take advantage of. In order to demonstrate credibility with this topic, theoretical perspective upon the brand image of the 26 investigated communes was provided to illustrate both the tourism potential of the territory and the valuable contribution that local authorities can make to brand development. In order to obtain the discussed information, quantitative and qualitative methods were employed: from observation and synthesis engaged in the literature and official websites review, to semi-structured interviews with 26 representatives of the local authorities (of each commune in the examined area) that were later analysed and expressed through descriptive, statistical, graphical and tabular data. Although the results show that local authorities are aware of tourism's importance to economic development, their choice of brand elements is rather questionable especially when considering territorial identity. However, some of the local authorities we interviewed did have a good understanding of the local elements that could be employed in territorial branding. They had not only correctly recognized nature-based aspects and cultural heritage attractions including customs and traditions, but had also expanded the cognitive perspective that outsiders tend to have with respect to an unfamiliar destination, by completing it with affective features that tourists equally appreciate.

Keywords: economic diversification, territorial development, brand elements, destination, mountain area, Cluj

Cite this article as: Răcăşan, B.S. \& Egresi, I. (2019). Tourism, Branding and Territorial Identity in the Rural Space. Local Authorities' Perspective. Territorial Identity and Development, 4(2), 18-38. DOl: http://doi.org/10.23740/TID220192

\section{INTRODUCTION}

Rural areas are undergoing tremendous transformation all around the world (Egresi, 2002). Small family farms are being consolidated into bigger farms, often owned by outsiders, and monoculture is becoming more and more prevalent. Moreover, the young and talented are leaving for better economic and social opportunities in cities and towns and rural communities are left struggling with population loss. As their population is rapidly aging, there is concern that 
many small communities will not survive. The situation is direst in peripheral areas which are characterized by low connectivity to the main markets (Salvatore, Chiodo \& Fantini, 2018). Here, by peripheral, we understand not only a distant geographic position relative to the main economic centre, but also a certain degree of economic, political, social or technological marginalization (Salvatore, Chiodo \& Fantini, 2018).

The European Union, through its Rural Development Policy (RDP), is promoting diversification of economic activity in order to achieve a balanced territorial development of rural economies and communities (European Commission, 2011). Similarly, in Romania, diversification of the rural economy is one of the key priorities of the National Rural Development Programs (Ilovan et al., 2016).

Tourism has often been mentioned as a possible remedy for the problems listed above and an important driver of socio-economic change (Baker \& Cameron, 2008; Găman, Răcăşan \& Potra, 2017; Matei-Gherman, 2010; Salvatore, Chiodo \& Fantini, 2018; Tirado-Ballesteros \& Hernández-Hernández, 2016). Indeed, in Europe, many rural communities, especially in peripheral areas affected by changes in the agricultural systems, are hoping to make tourism an alternative development strategy (Kneafsey, 2000).

Still, as of today, there is very little tourism development in peripheral rural areas and only few people, mainly independent travellers, visit these destinations (Salvatore, Chiodo \& Fantini, 2018). Mainstream tourism is heavily concentrated in a few centres and areas (in general, cities, and sea and mountain resorts). Few tourist destinations exist in peripheral areas and those that exist are generally owned and operated by external capital rather than integrated into local economies (Kauppila, Saarinen \& Leinonen, 2009).

However, the situation may be changing. Worldwide, the trend is toward moving away from mass tourism and embracing alternative forms of tourism (Egresi, 2016a; Răcăşan, 2014; Răvar, 2012). Alternative tourism includes a variety of forms, some of which could take place in rural areas (from agri-tourism to nature-based tourism and to event or heritage tourism) (Egresi, 2002; Răcăşan, 2014; Răcăşan, 2015). These forms of tourism capitalize on a unique resource and are generally small in scale, thus considered friendlier to the environment and more ethical in their relationship with local communities (Egresi, 2016b). Also, travellers interested in practicing alternative forms of tourism are generally more educated, more interested in local cultures, and more willing to spend money in the local community (Bramwell, 2004). Given all these characteristics, tourism in its alternative forms is touted to be the ideal means for achieving local and regional development.

Rural tourism is clearly multifaceted, meaning that it covers numerous activities (Egresi, 2002; Lane \& Kastenholz, 2015; Răcăşan, 2014). Rural features that in the past were considered to be disadvantageous (isolation, lack of infrastructure and economic and social underdevelopment, and traditionalism) could be considered favourable today as more and more travellers are looking for more distinctive, more personalized and unique products (Marson, 2011, Răcăşan, 2018). Also, authenticity is very important today as rural tourism is based on the commodification of local cultural resources (Kneafsey, 2000) and is very sensitive to the existence of a 'sense of place' (Jepson \& Sharpley, 2015).

In order to benefit from the development of alternative forms of tourism, peripheral tourism destinations need to be pro-active (Chaperon \& Bramwell, 2013). They should get involved in tourism planning and use their territorial identity in order to create a unique brand and to market themselves even under a brand image (Răcăşan, 2018). Territorial brand and identity are very popular research topics in social sciences; however, they are very rarely employed in 
tourism studies although territorial identity might be one of the most important factors for the attraction of tourists (Jäntti, Tiensuu \& Rusko, 2013).

This study seeks to understand how local authorities perceive the benefits of tourism as an alternative economic activity that could sustain territorial development, as much as branding, through effective elements, and that could increase the chances of a destination to attract more tourists. For this to happen, the following research objectives became tributary to the aim of this paper:

o reviewing the main concepts of territorial identity, branding, territorial marketing;

o diagnosing the local authorities' awareness with respect to the significant role that tourism could play in terms of both economic diversification and alternative or conjunctive development strategy - by several analysis methods;

o identifying the communes that refer to agri-tourism and tourism as main activities;

o establishing the level of trust in the positive impacts of tourism in the presence/absence of a development strategy and funding for projects related to tourism;

o correlating the attitude of local authorities towards tourism with their brand proposals;

0 analysing the elements indicated by the local authorities for the process of shaping the brand image of the administrated commune;

o classifying the recommended identity features into major categories, from general to specific ones, supported by relevant examples;

0 ranking the brand elements from best represented and effective ones, to least invoked aspects, with respect to both natural and built environment;

o highlighting the novelty elements of territorial identity in the perception of local authorities compared to a theoretical perspective;

0 insisting upon the advantages of combined efforts of both insiders and outsiders within the branding process.

\section{THEORETICAL BACKGROUND}

Parallel with the deepening economic, political, and cultural globalization processes, over the last 20-30 years, observers have also noted a "quest for the (re)affirmation of the identity of places and regions", especially in some rural areas threatened by loss of cultural authenticity (Roca \& de Nazaré Oliveira Roca, 2007). In fact, we could safely state that territorial identity is shaped by the conflict between the processes of globalization and the struggle to maintain individualism (Castels, 1997) and is commodified with the purpose of being offered for consumption by tourists (Kneafsey, 1998).

Territorial identity derives from the uniqueness of the geographical space and is based on natural or cultural features associated with a certain bounded space (Alaoui \& Abba, 2019; Paasi, 2003). In fact, the specificity of territory is given by processes of interaction between the community and the surrounding environment (Pollice, 2003). Thus, territorial identity may include both elements of landscape, climate or hydrography (Carneiro, Lima \& Silva, 2015; Stoffelen et al., 2019) and cultural and social identifiers (Kneafsey, 2000; Ou \& Bevilacqua, 2017; Răvar, 2012; Roca, Oliveira \& de Nazaré Roca, 2016; Stoffelen \& Vanneste, 2018; Zbuchea, 2014). Some of these elements, such as landscape, local foods or dialects could be regarded as both 
determinants of identity and expressions of it (Simon, Huigen \& Groote, 2009). Identity is strengthened by the identification of locals with it (Paasi, 2003; Paasi, 2013) and by cultural factors that increase local community' sense of belonging (Birkner, Máhr \& Rodek Berkes, 2018; Pollice, 2003).

Identity is a social process through which a territory becomes institutionalized (Paasi, 2003). It could be associated with territories at any geographical scale (Paasi, 2002) and is an open and dynamic phenomenon, meaning that it can change with time (Banini, 2017; Pollice, 2003). Moreover, identity refers to something that is imagined, but "becomes real in people's lives" (Capello, 2018), or something that we make rather than something that we are (Hall, 1996).

Increasingly, territorial identity is included in local development strategies (Bâca, 2014). This is especially true in the European Union, where re-discovery and valorisation of territorial identity is considered to be a key factor in any local development strategy (Commission Europeène, 1994). These strategies rely on strengthening territorial identity by which Oliveira, Roca \& Leitão (2010) understand creating or deepening a sense of belonging among residents and increasing territorial attractiveness to outsiders. Enhanced territorial cohesion could constitute an important resource for the development of rural areas as demonstrated by a number of studies (Filimon, Nemeş \& Filimon, 2014; Lee et al., 2005; Ou \& Bevilacqua, 2017).

Rural areas are increasingly seen not only as places specialized in agricultural activities but also as places for leisure and tourism activities (Bessière, 1998). With this shift, many rural places are interested in establishing, re-gaining or enhancing their identity; it is widely known that, in tourism, identity is important in order to distinguish a destination from its competitors (Apetrei \& Surdu, 2017; Dredge \& Jenkins, 2003; Răvar, 2012). Rural areas are often associated with nature and authentic communities (Bessière, 1998). Traditions and authenticity are what draws tourists to the countryside (llovan et al., 2016; Plăiaş, Ghereş \& Pop, 2010). For example, Folgado-Fernández, Nunes \& Seco-González (2019) examined how organization of events, which are representative of the local identity, could contribute to the development of tourism. The study found that those events that are unique to a certain locality/region have attracted a greater number of tourists. However, too much emphasis on uniqueness and authenticity could lead to mystification of identity values in tourist areas which, in time, could determine the loss of authenticity and even the loss of territorial identity (Pollice, 2003).

In the Romanian context, the main elements of rural cultural identity were identified in the literature as being (Gligor et al., 2014; Mazilu, 2014; Mazilu \& Dumitrescu, 2012; Plăiaş, Ghereş \& Pop, 2010; Stanciu, 2017):

- houses built using local materials and a specific architecture;

- local folklore;

- local traditions and ways of doing things;

- traditional art and handicrafts (embroidery, ceramics, sculptures, etc.);

- local festivals and events;

- local gastronomy.

Besides cultural elements, certain unique natural elements could also become important identifiers of a rural area (Mazilu, 2014).

There could be differences between how the insiders and the outsiders view the territorial specificity of a destination (Pollice, 2003; Răcăşan \& Găman, 2015). From the perspective of 
outsiders, place identity is not so much based on actual features as it is a matter of image and this image is based on three components: cognitive, affective and conative (Baloglu \& McCleary, 1999; Pike \& Ryan, 2004; Kim \& Perdue, 2011). While the cognitive image is based on the knowledge of the physical attributes of the destination, the affective image denotes feelings about the destination attributes. Finally, the conative component refers to the likelihood of an individual to visit the destination in the near future.

Each person perceives a tourism destination in a distinct way (Buhalis, 2000), based on their knowledge, beliefs, feelings and overall perception of the destination (Crompton, 1979; Gartner, 1993). Often, this image will be formed based on a few initial impressions (Lee et al., 2012) or on personal experience (Litvin \& Mouri, 2009) or on individual interpretations of a place (Gallarza, Saura \& Garcia, 2002). According to Răvar (2012), it is the destination's cultural identity that tourists will remember the most after returning from a vacation. On the other hand, locals can also influence the way outsiders perceive their place through a so-called "projected image" (Djankov, Krastev \& Yancheva, 2018). This is produced through combined efforts of local authorities and specialized marketing (branding) companies and the end result of this collaboration is a unique positive image ("territorial brand") that is promoted on many channels ("territorial marketing") (MacKay \& Fesenmaier, 2000; Petrea et al., 2013). Building territorial brands is a way of promoting the territory as a tourist destination (Lorenzini, Calzati \& Giudici, 2011).

There is a positive association between identity, branding and marketing of a territory. A study by Charters and Spielmann (2014) concluded that strong territorial brands are generally associated with the identification and valorisation of certain local or regional features that are unique or irreproducible (Blain, Levy \& Ritchie, 2005). These territorial features could then be employed to provide an advantage for that particular region/locality over other territorial units (Plumed Lasarte, Tena Prazuelo \& Elboj Saso, 2011). This is the case of tourist destinations (Orth et al., 2012). On the other hand, an attractive brand could help a place communicate its main features better and thus attract more tourists to the detriment of places with weaker or negative brands (Zbuchea, 2014) leading to tourism development (Middleton, 2011).

Of course, the process of territorial branding takes time and is very complex (Konecnik \& Go, 2008). Whether a brand identity will be successful or not depends on many factors, including its positioning strategy (Djankov, Krastev \& Yancheva, 2018). Place branding could help with territorial marketing and ensure its success (Kavaratzis \& Ashworth, 2008). At the same time, successful territorial marketing could lead to place branding (Litvin \& Mouri, 2009; Zbuchea, 2014) and could generate or enforce a competitive territorial identity (Dredge \& Jenkins, 2003).

In conclusion, we believe that territorial marketing based on identity could change the image of a destination (Megri \& Bencherif, 2014) and could constitute an effective tool to attract resources to develop a region or a locality (Paiva et al., 2019).

\section{METHODOLOGY}

It should be clearly stated from the very beginning that this study is part of a wider research focused on tourism as a phenomenon and complex activity within the rural-mountain area of Cluj County (Figure 1). However, the subject was solely tangential to that discussion and was limited to a series of proposals regarding the brand image of each commune from the investigated territory. 


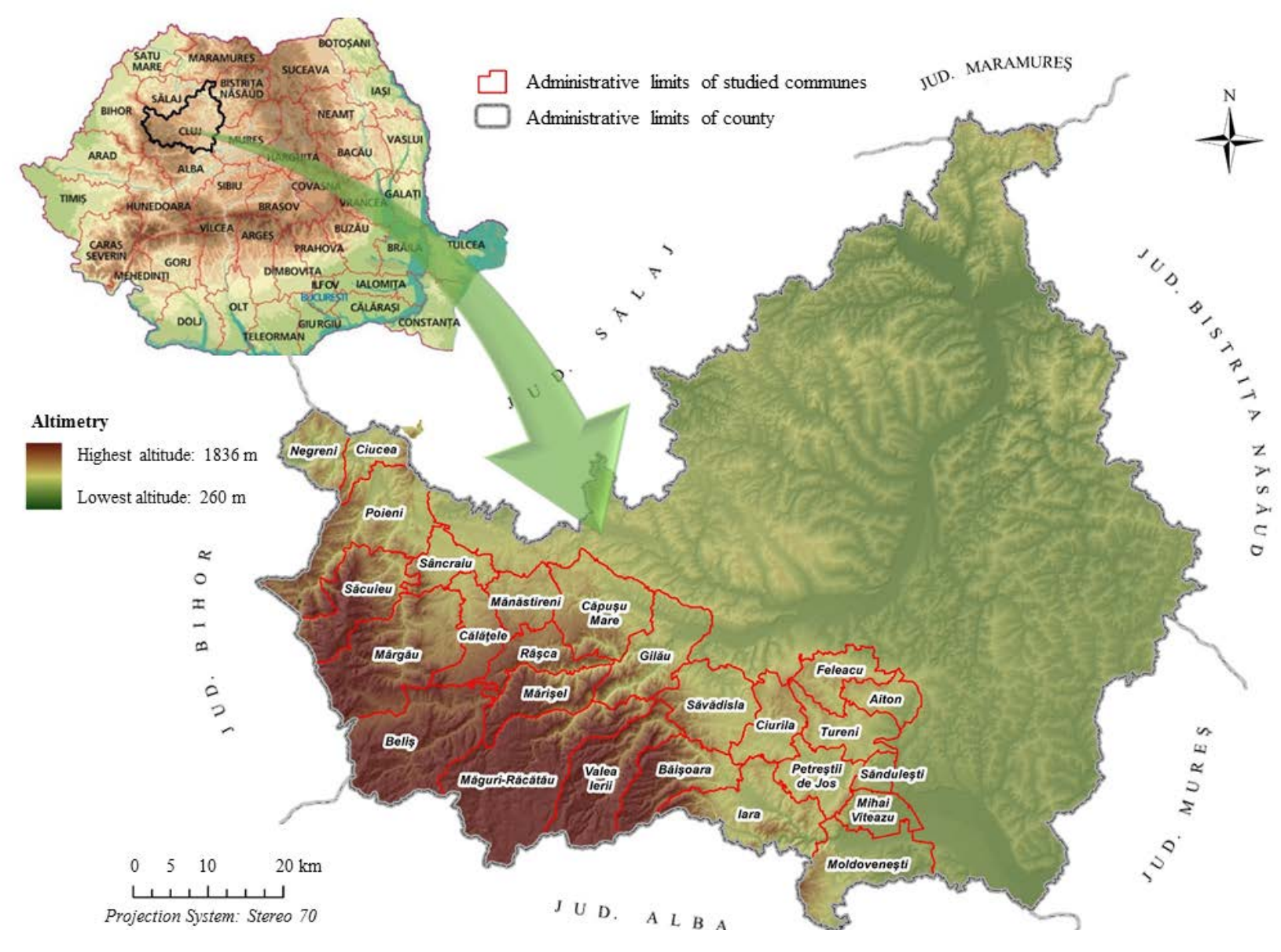

Figure 2: Map of the area under study 
For this reason, the initial proposals that were resumed in the second part of this paper, both through a photographic collage (Figure 2) and tabular representations (Table 1), were enclosed with fragment answers provided by local authorities that exclusively involved the ideas that did not repeat the theoretical perspective. Thus, the emphasis was placed on the role of novelty in the perception of the mayors and deputy mayors of each of the 26 territorial-administrative units that belong to the study area, who had been previously interviewed by one of the authors. The semi-structured interview employed in this study included 12 questions, but only the answers to three of these questions were analysed for the purpose of this study, namely: tourism development strategies over the past few years, funding opportunities and opinions about suitable brand elements.

In a wider sense, everything can be reduced to territorial development, whether it is branding for promoting a destination, or tourism itself as a complementary activity within the economic system and even more in the case of rural areas. While branding investigation was supported by primary data processing, respectively, identifying, inventorying, classifying and highlighting the most important features in the branding process; tourism examination involved the analysis of secondary data that were previously collected from an official website where the representatives of all town halls in Romania had posted information regarding several aspects of general interest (the structure of public institution, communes' surface, population, location, tourist attractions events, etc.), along with the ones taken into account for this study, namely the economic activities.

Thus, besides the classical observation, analysis and synthesis, the study implied semi-structured interviews, as well as statistical and cartographic methods and photographic representations to interpret the results.

\section{RESULTS AND DISCUSSION}

As it was previously stated, the diversification of economic activity is a key priority for the world. Becoming part of the European Union, Romania subordinated both its Rural Development Policy and its National Rural Development Programs to this goal. Thus, this preoccupation is also becoming more and more popular amongst rural communities, which have already understood that more diversified economic activities could lead to a more balanced territorial development.

Naturally, agriculture continues to maintain viable rural communities as it has been doing for centuries and the study area is no exception. After consulting the official website of the town halls in Romania ${ }^{1}$ for specialised information, it emerged that more than three quarters of the investigated communes had specifically indicated either "agriculture" (21 communes; three of them also included potato production, and one, vegetable crop as further detail) or "livestock breeding" (21 communes; four of them pointed out animal husbandry), while half of the communes (13) mentioned both occupations as main economic activities.

They were followed by other important primary economic activities for the examined ruralmountain area, that turned out to be forestry or logging and sawmilling (cited by 14 communes) and quarrying (six communes: coarse sands, feldspar, limestone exploitation), even mining (iron exploitation), and subsequently used building materials in the construction industry. The latter example, along with other industries such as the energy one or the food processing industry

\footnotetext{
${ }^{1}$ Ghidul Primăriilor [Guide of the City Halls] (2020).
} 
(e.g. bakeries, dairy), based on agricultural raw materials, are tributary to the secondary sector of the economy, making their way to the service industry, also known as the tertiary sector of the economy. Thus, from "public catering services" and "freight transport" to the most general "providing services" of their economy - less than three communes stated as important vectors - two types of activities stood out in terms of frequency of answers: retail and wholesale activities and tourism.

While the former found correspondence in the answers of almost $50 \%$ of the investigated communes, the latter was listed among the top leading activities, next to those from the primary and secondary sectors of the economy, in 21 cases out of 26 . Therefore, the $80 \%$ of the researched territorial-administrative units that referred to agri-tourism (nine out of the 21 communes) or simply tourism (12 communes out of 21 ) stand as proof for an increasing degree of awareness, amongst local authorities and communities, regarding not only the diversification of economic activity, but also the significant contribution that tourism could have as an alternative development strategy or a conjunctive one. Not surprisingly, without exception, all nine communes that reported agri-tourism as their main economic activity, also signalled the high priority role of animal husbandry in the context of local development, revealing interdependence and connections between the two occupations.

In order to test this idea and the level of trust in the positive impacts of tourism within an area that could become an alternative to the mass tourism destinations, an analysis of two types of actions taken by local authorities was performed. During the interview, they were first asked if they had designed tourism development strategies over the past few years and, secondly, if they had been searching for funding opportunities and applied for them. Having accomplished these two purposes, intending to or on the contrary, neglecting them both, revealed a lot about the consideration of tourism's impact.

However, what is more important than the ascertainment that $50 \%$ of the communes within the rural-mountain area of Cluj County seem to have understood the importance of tourism - and, thus, have benefited from both strategies and funding meant to support tourism - is the relationships between their involvement (or lack of it) and the local authorities' perceptions of identity and territorial branding.

Thus, by combining the positive and negative answers, or in other words, their determination to develop tourism in the administrated area - due to their trust in its potential - with the brand discussion, four different approaches emerged:

0 the existence of both strategies and funding sources for tourism development (46.2\% or 12 communes) that suggest higher levels of consciousness concerning the positive implications and effects of tourism, gravitating towards a wide range of choices when asked to associate brand elements with the territorial identity - from general to specific, from natural to cultural, from cognitive to affective, etc.

0 the absence of a development strategy, but with funds employed $(19.2 \%$ or five communes), whose focal point is represented by economic resources with tourist functions (water storage reservoirs), cultural (churches) and culinary tourism resources (forestry and dairy products);

0 the existence of a tourism development strategy, but no funds allocated ( $15.4 \%$ or four communes), whose centres of interest are mainly traditions and natural tourist attractions;

0 the absence of both strategies and funding for projects related to tourism (19.2\% or five communes), despite its great potential, not only nature-based but also for entertainment with tourism infrastructure and facilities for nautical and winter sports. 
It is interesting to note that the level of investment of time, energy and other resources on the part of local authorities is also reflected in the complexity of the answers regarding the quantity and quality of brand elements and their viability.

On this subject, a whole discussion about strongly branded destinations and poorly branded ones could be held. However, what is worth to be considered is the uniqueness that is aimed when a destination is promoted through its (brand) image and products, in order to differentiate it from its competition. As both theory and practice demonstrate, the features of geographical space, together with the related territorial identity derived from interactions between local communities and the environment, are an intrinsic part of brand attributes. Not only can they not be ignored, but also a proper identification of defining aspects of a territory, at any geographical scale, would act as a catalyst to enhance the attractiveness of the area and thus contributing to its development. Some representatives of the local authorities seem to have understood this better than others, as results show.

One quarter of those that were interviewed did not provide us with answers to our questions about the specific elements that they would choose in the process of shaping the brand image of the administrated commune. They solely referred to:

o natural aspects such as "nature" or "the landscape" or "the topography of the area," whether they mentioned "mountains" or not, without any other kind of concrete suggestions and forest products derived from forestry for direct consumption or commercial use ("blueberries, raspberries"). The mayors of two neighbouring communes from the mountain area, located in the southern part of Cluj County, not only responded in very general terms, but also indicated identical symbols for the brand concept, namely the fir tree and the mushroom. However, while one of them did not continue the sequence of thoughts, the other one added "mountains and skiers," along with berries that although did not change the high degree of generality of the answer, made it a little less vulnerable to competitions.

o cultural heritage including both material (traditional products derived from "handicrafts", "specific fabrics", "culinary products") and immaterial aspects - for instance "local holidays" and the omnipresent and eternal combination of "customs and traditions." The latter category coincided with the second highest degree of generality, - after the questionable "anthropic" concept, without any other reference - concerning the idea of brand development, because it is very difficult to operationalise in the absence of concrete examples. Furthermore, it is quite hard to identify a local habit within small territorial-administrative units (this being the case of the study area, where the largest commune by area, Beliş, is covering $206.5 \mathrm{~km}^{2}$ and the smallest one, does not occupy more than $45.27 \mathrm{~km}^{2}$ ), or a tradition that is unique and unrepeatable to such an extent that only one community resonates with (in the context of the least populous investigated commune, Valea lerii, which has less than 900 inhabitants), when the ones that gave these answers - born and raised there, most of them - did not detail the subject.

The other three quarters of the representatives of local authorities were less ambiguous in expressing their opinions towards defining brand elements for their communes. As might be expected, the previous two categories were once again taken into consideration, but this time with the help of suitable examples. Given the physical-geographical characteristics of the study area, particular emphasis was placed on gorges (Turda Gorges, Tureni Gorges, Păniceni Gorges), natural lakes and waterfalls (e.g. Ciucaş), and other protected natural areas (Deers' Valley, "Sequoia tree" forest reservation), along with artificial lakes, both reservoirs (Tarniţa, Gilău, Someşu Cald, Fântânele, Drăgan) and fishponds (Ciurila Lakes). 
It is worth appreciating that out of the total 38 protected natural areas in the examined area (Răcăşan, 2018), nine have been included in the brand elements: two of national interest (Turda Gorges and Tureni Gorges) out of the 11 existing ones, and other seven protected natural areas of county interest (Tarniţa Reservoir, Gilău Reservoir, Someşu Cald Reservoir, Fântânele Reservoir, Drăgan Reservoir, Pănicenil Gorges and Deers' Valley) out of the 27 existing ones. It would have been excellent if this number had been greater, confirming a strong knowledge in terms of natural tourist resources, but one could also presume that only the most relevant examples of protected natural areas were referred to, because it is not about being exhaustive but rather selective in a practical manner.

With respect to the built environment, all kinds of man-made structures and constructions were brought into discussion, without leaving aside neither the tangible nor the intangible major categories of tourist attractions, as follows: five historical ones (Sănduleşti archaeological site, Bologa Roman camp, the ruins of the medieval fortress Gheczi in Liteni, the medieval Bánffy Castle in Gilău, Szécsenyi-Mikes Castle in Săvădisla); eight religious ones (the Reformed Church in Văleni, Călăţele commune; Feleacu church; the Reformed Church in Mănăstireni and the Orthodox wooden church in Bica village, both in Mănăstireni commune; Râşca Transilvană Monastery; Vlaha Catholic Church, Finişel and Stolna wooden churches, all three in Săvădisla commune; Greek-Catholic and Unitarian churches in Sănduleşti commune); one cultural structure ("Octavian Goga" Museum Ensemble in Ciucea); one economic edifice with tourist function (Drăganului River Dam - the only one, fully and clearly, expressed - and all the other mentioned-above and implied water storage reservoirs within the mountain sector).

Given the total number of anthropic tourist resources that coexist within the examined ruralmountain area in Cluj County (comprising 26 communes), it can easily be established the percentage of most frequent suggestions for the branding process. From a total number of:

o 226 historical objectives and edifices (Răcăşan, 2018), 2.2\% were mentioned within the answers of local authorities, more precisely: $1.4 \%$ out of the 207 archaeological vestiges and $10.5 \%$ out of the 19 habitational buildings with architectural value (manors, houses, castles and palaces; considering only the four existing castles, $50 \%$ were pointed out);

o 250 religious buildings (Răcăşan, 2018), 3.2\% were indicated by the representatives of local authorities within their examples of brand elements; however, a considerable increase in the percentage emerged when referring only to the 54 churches with historical monument status, ensuing a $12.9 \%$ rate of acknowledgment or to the 24 wooden churches out of which $12.5 \%$ were hinted in the answers of the local authorities or even a important proportion solely related to the seven monasteries out of which $14.2 \%$ were mentioned;

o 66 cultural edifices (Răcăşan, 2018), 1.5\% were recorded in the analysed statements; still, 59 out of them are monuments that were completely ignored by the local authorities in the branding process and for this reason, invoking only the six museums and the ethnographic collection within the one in Ciucea brought the initial percentage of $1.5 \%$ up to $16.6 \%)$;

0 17 economic edifices (Răcăşan, 2018), with tourist function (e.g. dams, hydroelectric power stations), $5.8 \%$ were cited by the interviewees if we reduce the accepted examples solely to dams; yet, if we take into account the reservoirs as well, $29.4 \%$ of the economic tourist resources were proposed as suitable brand elements within the investigated area.

All things considered, it can be noticed that the local authorities value most in man-made tourist resources: castles, water storage reservoirs, museums, monasteries and churches that had been 
declared historical monuments or, in other words the historical buildings, followed by economic and cultural edifices, and finally the religious constructions that possess a certain amount of attractiveness able to make a commune stand out from everywhere else.

Concerning the intangible heritage elements, apart from customs and traditions related to "culture and religion" (as it was stated in one answer), folklore and knowledge play the most important role in the formation of territorial identity and should be kept in mind when shaping the brand image. While knowledge is often reflected in everyday life occupations, folklore must do more with arts and crafts within a rural space. Its traits are being influenced by the wood civilization, the pastoral and agro-pastoral society - as in the case of the mountain sector of Cluj County. The representatives of local authorities proved that they were partially aware of this role because only approximately half of them referred to: "sheep breeders" when exemplifying occupational activities; "folk art" and "traditional folk costume" with respect to arts and crafts; "the young men of the village" famous for their Christmas carol interpretation, songs and folk dances. Everyday life skills, from the apparently banal cooking of an ordinary meal (i.e. polenta with butter, sour cream and milk a.k.a balmoş) to traditional food processing techniques and exquisite traditional "gastronomic specialities" associated with "dairy and cheese" and "organic products from berries" (e.g. jams, syrups, rosehip jam, etc.).

With the proper approach associated with tourists' desires in terms of direct experience - what they want to do and see, to hear and taste, to feel about - all of these elements could become key factors in the development of commune brand because they involve both cognitive and affective components that tourists could relate to when consuming the tourist product within the destination.

Taking into account the fact that even "insiders" (i.e. local authorities) relate differently to the concept of identity or specificity that could support the territorial brand of a destination (i.e. the communes which they administer), it comes as no surprise that "outsiders" (e.g. researchers, stakeholders, tourists) perceive it in a distinct way as well. This is a result of each individual's experience, whether it is mainly based on theoretical knowledge or upon emotions and beliefs that have been reinforced over time.

In order to reveal these variations in the perception of identity, brand elements - and thus, the opinion about branding - that could be pertinent enough to build a positive image of the investigated area and to promote it as an easy to identify and distinguish tourist destination, two types of perceptions were confronted: the answers directly provided by the local authorities and the brand image proposals found in specialized literature (Figure 2). The latter is the result of extracting information from the monograph of Cluj County and from the monographs of the communes under study, related tourist guides, specialized websites such as Romania's Geographical Encyclopaedia, Guide of the City Halls, the Association of Romania's Communes, etc., that were subsequently represented using pictures from the internet (e.g. aerial photos) or from personal archives (for details, cf. Răcășan, 2018).

The purpose of juxtaposing the two viewpoints was not to create a comparison/contrast effect and highlight the advantages and drawbacks or limitations of one or the other, but to raise awareness about the process of territorial branding, whose success could only occur if efforts from both sides (insiders and outsiders) are combined. 


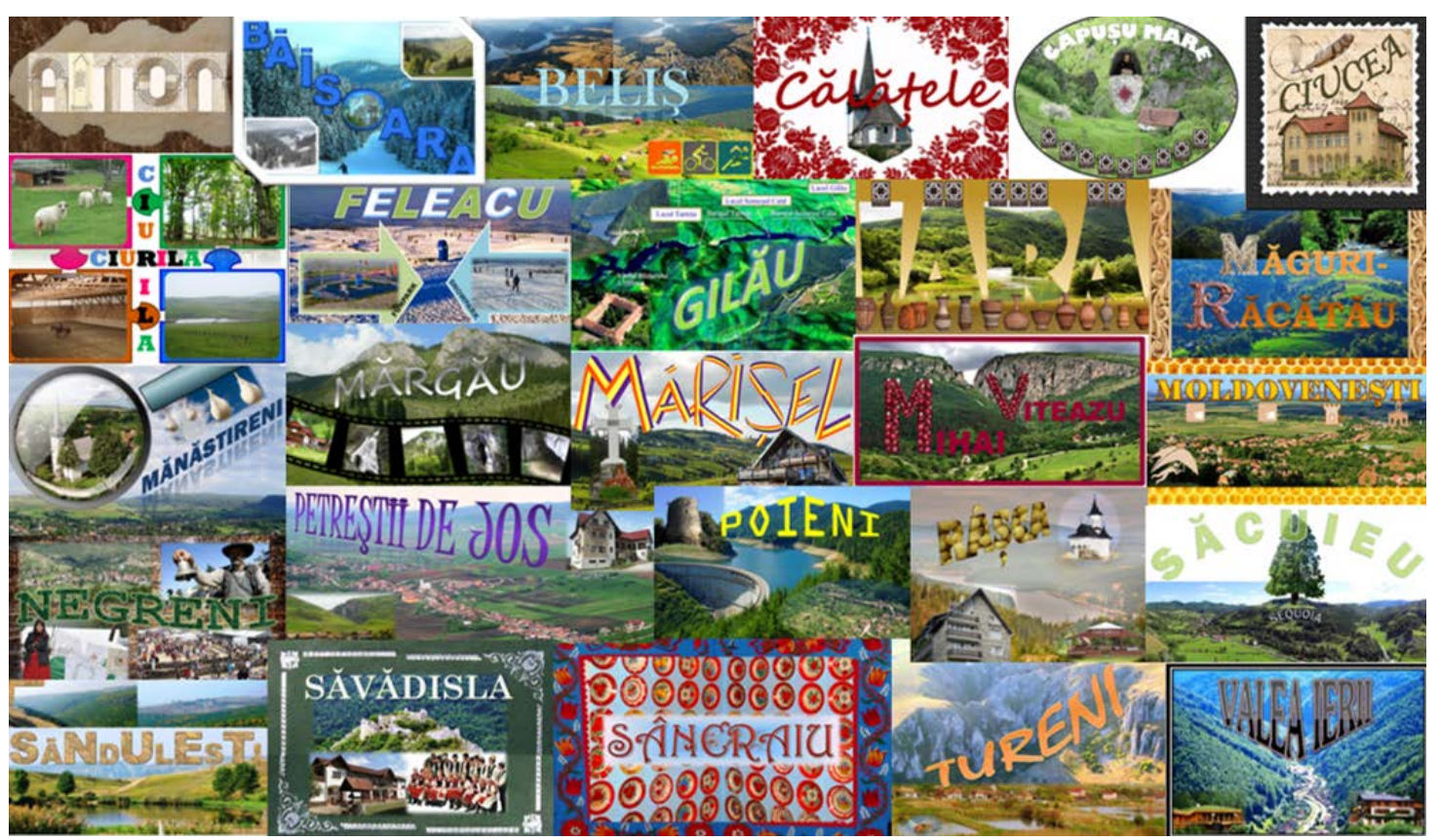

Figure 2: Collage of the brand image proposals

Source: Răcăşan (2018), with changes

Moreover, as it was mentioned above, the practicability of branding and identity has nothing to do with complex inventories of all tourist resources within a territory, but rather with the identification and valorisation of irreproducible or unique features, all the more so as the tourist potential of the examined communes is slightly various. According to the Ministry of Agriculture and Rural Development, ${ }^{2}$ on a scale from 1 to 10 points, the average value of the study area is estimated to be 4.08 because $54 \%$ of the territorial-administrative units received 4 points, $19 \%$ only 3 points, other $19 \%$ received 5 points, while 6 points were allotted to only one commune (Table 1). Thus, without being granted with scores that indicate high potential values, it is interesting to notice how the tourist attractiveness is related to brand elements. Without question, all the opinions in Table 1, mainly the ones extracted from the literature, could be supplemented with more examples of nature-based or cultural attractions (after all, it is only a model of proposals); the same way as for the last column, where the information provided by local authorities is deliberately missing the overlapping ideas so that only the elements of novelty regarding the specificity of the administrated commune would be emphasized.

It can be observed that some brand elements indicated by those who were interviewed do not coincide with the classical concept of destination image consisting in the physical attributes of the territory, but they rather accentuate the affective side of the destination image. One word stands out: "hospitality". Many local authorities used this word not only because they felt they identified with it, but also because it was a key factor that influenced the way outsiders perceived the commune in the context of a tourist destination.

${ }^{2}$ Lista comunelor cu punctajul acordat în funcție de potențialul turistic | Ordin 567/2008 [List of Communes with Scores according to Tourist Potentiall Order 567/2008] (2020). 
Table 1: Territorial identity quintessentialised in tourist destination branding ideas and proposals

\begin{tabular}{|c|c|c|c|}
\hline Commune & $\begin{array}{l}\text { National } \\
\text { authorities' } \\
\text { perspective on the } \\
\text { tourism potential }^{3} \\
\end{array}$ & $\begin{array}{l}\text { Theoretical perspective } \\
\text { (model proposal) - explanation for } \\
\text { the photographic collage }\end{array}$ & $\begin{array}{l}\text { Local authorities' } \\
\text { perspective } \\
\text { (without intersected } \\
\text { elements) } \\
\end{array}$ \\
\hline Aiton & 4 & $\begin{array}{l}\text { the Roman milestone (miliarium dating } \\
\text { back to } 108 \text { A.D.) and a sheepskin as a } \\
\text { symbol of fellmongering centre }\end{array}$ & $\begin{array}{l}\text { unpolluted area, } \\
\text { traditions and customs }\end{array}$ \\
\hline Băişoara & no data available & $\begin{array}{l}\text { mountainsides and ski slopes, Băişoara } \\
\text { resort, during winter and summer, } \\
\text { demonstrating its mix profile, mainly } \\
\text { focused on winter sports that benefit } \\
\text { from a high number of competitions }\end{array}$ & $\begin{array}{l}\text { blueberries, raspberries, } \\
\text { mushrooms }\end{array}$ \\
\hline Beliş & 4 & $\begin{array}{l}\text { Fântânele Reservoir, Apuseni Nature } \\
\text { Park and tourist activities symbols } \\
\text { related to competitive events } \\
\text { organised inside the territorial- } \\
\text { administrative borders }\end{array}$ & $\begin{array}{l}\text { an image from the } \\
\text { hunting sphere }\end{array}$ \\
\hline Călăţele & 4 & $\begin{array}{l}\text { the Reformed Church in Văleni, } \\
\text { representative for the Hungarian } \\
\text { cultural heritage, seams; emblematic } \\
\text { for traditions and customs }\end{array}$ & $\begin{array}{l}\text { natural tourist resources } \\
\text { in Dealu Negru and } \\
\text { Călăţele Pădure }\end{array}$ \\
\hline $\begin{array}{l}\text { Căpuşu } \\
\text { Mare }\end{array}$ & 3 & $\begin{array}{l}\text { Păniceni Gorges (protected natural } \\
\text { area); an illustrative image for the } \\
\text { rural space (an old lady sewing); nine } \\
\text { indicators for the nine churches } \\
\text { declared historical monuments }\end{array}$ & folk art, sheep breeders \\
\hline Ciucea & 5 & $\begin{array}{l}\text { "Octavian Goga" Museum Ensemble } \\
\text { (historical monument) and the } \\
\text { correspondent annual national poetry } \\
\text { festival }\end{array}$ & relief, Ciucea Pass \\
\hline Ciurila & 4 & $\begin{array}{l}\text { "Windmill" (Moara de Vânt) Zoological } \\
\text { Park, Gecko Adventure Park, "Napoca } \\
\text { Sport Horse" Riding Centre, Ciurila } \\
\text { Lakes }\end{array}$ & nature, Măgura Peak \\
\hline Feleacu & 4 & $\begin{array}{l}\text { Feleac Massif and ski slope, supporting } \\
\text { the winter snowpark and summer } \\
\text { funpark }\end{array}$ & the church, Deers' Valley \\
\hline Gilău & 5 & $\begin{array}{l}\text { the three reservoirs (Gilău, Someşul } \\
\text { Cald and Tarniţa), Tarniţa Dam, } \\
\text { Someşul Cald river and Bánffy Castle }\end{array}$ & - matching perspective - \\
\hline lara & 4 & $\begin{array}{l}\text { Arieş Defile protected area and the } \\
\text { ceramic products of the local potters; } \\
\text { the eight religious and residential } \\
\text { buildings classified as historical } \\
\text { monuments, represented by the } \\
\text { related indicators }\end{array}$ & $\begin{array}{l}\text { the anthropic heritage; } \\
\text { traditions, customs, local } \\
\text { holidays, the relief of the } \\
\text { area }\end{array}$ \\
\hline
\end{tabular}

${ }^{3}$ Lista comunelor cu punctajul acordat în funcție de potențialul turistic | Ordin 567/2008 [List of Communes with Scores according to Tourist Potential| Order 567/2008] (2020). 


\begin{tabular}{|c|c|c|c|}
\hline $\begin{array}{l}\text { Măguri- } \\
\text { Răcătău }\end{array}$ & 3 & $\begin{array}{l}\text { protected natural areas: Someşul Rece } \\
\text { headwaters and Răcătău Valley, } \\
\text { Someşul Rece Defile and Răcătău } \\
\text { Defile, etc.; wood carvings indicating } \\
\text { both the wood civilization and the } \\
\text { presence of a folk craftsman } \\
\text { specialized in wood engraving }\end{array}$ & $\begin{array}{l}\text { the young men of the } \\
\text { village, balmoş (a } \\
\text { specific dish) }\end{array}$ \\
\hline $\begin{array}{l}\text { Mănăsti- } \\
\text { reni }\end{array}$ & 4 & $\begin{array}{l}\text { the Reformed Church in Mănăstireni, } \\
\text { as focal point and dairy products } \\
\text { represented by cheese obtained } \\
\text { through the ecological method - by } \\
\text { gathering in the gauze and placing it } \\
\text { on the drain }\end{array}$ & $\begin{array}{l}\text { the Orthodox wooden } \\
\text { church in Bica village }\end{array}$ \\
\hline Mărgău & 4 & $\begin{array}{l}\text { White Stones, Vârfuraşu Cave, The } \\
\text { Great Cave of the Fira Valley, Stanciu } \\
\text { Valley Gorges and Răchiţele Waterfall } \\
\text { - revealing a high density of protected } \\
\text { areas; Şuşman Guesthouse as a symbol } \\
\text { for rural tourism }\end{array}$ & $\begin{array}{l}\text { building a dairy factory } \\
\text { and registering the } \\
\text { products under specific } \\
\text { names, building a } \\
\text { furniture factory and } \\
\text { using new names }\end{array}$ \\
\hline Mărişel & 3 & $\begin{array}{l}\text { a typical landscape from Gilău } \\
\text { Mountains, Moţilor Chalet and the } \\
\text { Cross of lancu monument, where } \\
\text { hundreds of participants gather every } \\
\text { year for the traditional feast that } \\
\text { commemorates the leader and military } \\
\text { hero of the 1848-1849 Revolution: } \\
\text { Avram lancu. }\end{array}$ & $\begin{array}{l}\text { Mărişel dairy and } \\
\text { cheese; jams, syrups, } \\
\text { berries }\end{array}$ \\
\hline $\begin{array}{l}\text { Mihai } \\
\text { Viteazu }\end{array}$ & 5 & $\begin{array}{l}\text { Turda Gorges Nature Reserve (in the } \\
\text { Trascău Mountains), hosting approx. } \\
60 \text { caves; Mihai Viteazu red onion } \\
\text { wreath, illustrative for the commune } \\
\text { and the related event: the Onion } \\
\text { Festival }\end{array}$ & Ciucaş Lake and waterfall \\
\hline $\begin{array}{l}\text { Moldove- } \\
\text { neşti }\end{array}$ & 4 & $\begin{array}{l}\text { the panoramic view of the Lower Arieş } \\
\text { River Corridor and iconic symbols for } \\
\text { the fishponds in Bădeni and Stejeriş, } \\
\text { the castle and churches that were } \\
\text { declared historical monuments; } \\
\text { framed by the honeycomb design } \\
\text { signalling the bee products processed } \\
\text { in the commune }\end{array}$ & $\begin{array}{l}\text { hospitality of people, } \\
\text { Moldoveneşti onion, } \\
\text { gastronomic specialties }\end{array}$ \\
\hline Negreni & 6 & $\begin{array}{l}\text { a wide-angle representation of the } \\
\text { geographical location (at the foot of } \\
\text { the Plopiş Mountains) and pictures } \\
\text { taken during the famous Autumn Fair } \\
\text { in Negreni }\end{array}$ & $\begin{array}{l}\text { preservation of local } \\
\text { traditions, culinary } \\
\text { products, area-specific } \\
\text { seams }\end{array}$ \\
\hline $\begin{array}{l}\text { Petreştii } \\
\text { de Jos }\end{array}$ & 4 & $\begin{array}{l}\text { the perspective that the commune has } \\
\text { on the Turda Gorges used as } \\
\text { standpoint, also valued by Laura } \\
\text { Guesthouse in Petreşti Depression }\end{array}$ & - lacking perspective - \\
\hline Poieni & 5 & $\begin{array}{l}\text { Drăgan water storage reservoir and } \\
\text { the related dam situated in the }\end{array}$ & - matching perspective - \\
\hline
\end{tabular}




\begin{tabular}{|c|c|c|c|}
\hline & & $\begin{array}{l}\text { Vlădeasa Mountains; Bologa medieval } \\
\text { fortress and Valea Drăganului village }\end{array}$ & \\
\hline Râşca & 3 & $\begin{array}{l}\text { Fântânele Reservoir and the } \\
\text { homonymous tourist resort of local } \\
\text { interest (represented by Bianca Hotel } \\
\text { and the pavilion); Râşca Transilvană } \\
\text { Monastery; Râşca potatoes }\end{array}$ & landscape, hospitality \\
\hline Săcuieu & 4 & $\begin{array}{l}\text { the Sequoia tree strategically placed } \\
\text { on the top of Henţ Peak (in the } \\
\text { Vlădeasa Mountains) }\end{array}$ & $\begin{array}{l}\text { traditional folk costume, } \\
\text { traditional food products } \\
\text { (Săcuieu cheese, organic } \\
\text { products prepared from } \\
\text { berries) }\end{array}$ \\
\hline Sănduleşti & 4 & $\begin{array}{l}\text { the stone quarry and the two existing } \\
\text { fishponds: Tăul Mare and Tăul Mic; the } \\
\text { image of the Turda Gorges which is } \\
\text { often associated with this commune }\end{array}$ & $\begin{array}{l}\text { Tur Gorges, the } \\
\text { archaeological site, the } \\
\text { Greek-Catholic and } \\
\text { Unitarian churches, } \\
\text { mountain, flowers }\end{array}$ \\
\hline Săvădisla & 4 & $\begin{array}{l}\text { the ruins of Liteni medieval fortress; } \\
\text { The Old Mill Inn as a symbolic } \\
\text { accommodation unit; the traditional } \\
\text { folk costume, customs and traditions; } \\
\text { leather goods produced by craftsmen } \\
\text { in Lita village }\end{array}$ & $\begin{array}{l}\text { Szécsenyi-Mikes Castle } \\
\text { in Săvădisla, Vlaha } \\
\text { Catholic Church, "Fossil" } \\
\text { Numulites, Finişel and } \\
\text { Stolna wooden churches }\end{array}$ \\
\hline Sâncraiu & 4 & $\begin{array}{l}\text { an impressive number of brightly } \\
\text { coloured ceramic plates that serve as } \\
\text { an indicator for the record number of } \\
\text { agritourist guesthouses ( } 43), \text { with } \\
\text { Hungarian influences some of them } \\
\text { illustrated by the hand-painted } \\
\text { furniture }\end{array}$ & $\begin{array}{l}\text { cultural and religious } \\
\text { customs and traditions; } \\
\text { traditional products } \\
\text { (handicrafts, rosehip } \\
\text { jam) }\end{array}$ \\
\hline Tureni & 5 & $\begin{array}{l}\text { The Tureni Gorges and fishponds } \\
\text { (Mărtineşti Lakes) best for recreational } \\
\text { activities, especially rock climbing and } \\
\text { fishing }\end{array}$ & $\begin{array}{l}\text { Miceşti - picturesque } \\
\text { village }\end{array}$ \\
\hline Valea lerii & 3 & $\begin{array}{l}\text { lara Valley (protected area) which } \\
\text { crosses the Muntele Mare, ideal for } \\
\text { adventure tourism and hiking; Lara } \\
\text { Guesthouse, an iconic accommodation } \\
\text { unit for the commune }\end{array}$ & fir trees, mushrooms \\
\hline
\end{tabular}

Source: Răcăşan (2018), revised and updated

Other symbols such as "blueberries, raspberries, mushrooms", the "onion", the "fir tree" and "flowers" need further transformation in design and composition in order to be identified under different conditions and to be associated solely with one destination/commune. Likewise, dairy products, especially cheese and milk, or jams and syrups prepared from berries and other fruits, should be customized and developed under the brand identity that they share values with, if a higher purpose (i.e. territorial brand) than the solely commercialisation is aimed at.

Instead of suggesting brand elements, some representatives of the local authorities made strategic recommendations that regard the current and future state of some existing assets. Thus, the "customs" were once again brought into discussion in the form of "preserving local traditions" proposals; while other ideas involved flourishing businesses based on dairy products 
and wooden furniture - both derived from the processing of agricultural (animal farming) and forestry - "building a dairy factory and registering the products under specific names; building a furniture factory and using new names different from existing ones." In terms of economic development, the last two ideas could be classified as suitable, although they could be perceived as too oriented towards the primary and secondary sectors of the economy. However, as long as we are not dealing with a misunderstanding of the concepts (that could have negative effects upon the economy) and a minimization of the role of tourism in its long term development, the two proposals might have tourist potential as well. For instance, they could be associated with cultural tourism based on food and handicraft, with showcased production, souvenir production which could be the basis of future brand elements that could be used for designing a brand image in the context of a tourist destination.

However, approximately one third of the answers draw attention to the great potential that natural tourist attractions hold - one that cannot be underestimated or ignored if competitive brands are aimed at. Two situations distinguished between specific and general examples. In the former case, examples such as Măgura Peak, Deers'Valley, Ciucaş Lake and waterfall point to the usefulness of focusing on the aspects that those who oversee the branding process should be mindful of. The latter case is also meaningful because it compels the authors of branding either to expand the reference field and to check for other options in terms of "natural tourist resources", "topography", etc., or to reduce it to a specific category that could have been omitted at first sight (e.g. "an image from the hunting sphere").

The well-known propensity that tourists have for the built environment aspects generated less focusing on the natural wonders than on the man-made attractions within the first column of proposals; eight communes lack natural elements whereas only four, out of 26 , lack anthropic ones within the envisaged brand image designs. Irrespective of the matching perspectives that the researchers and local authorities share, the number of answers of the latter was also double in terms of cultural and human-made tourist resources compared to their recommendations based on the natural ones of the commune within the branding process.

Some distinguished themselves through accuracy and exactness, indicating both the attraction and the location ("Orthodox wooden church in Bica village", "Szécsenyi-Mikes Castle in Săvădisla, Vlaha Catholic Church, Finişel and Stolna wooden churches"). Others require a certain amount of knowledge regarding the tangible and intangible cultural heritage in order to make perfectly clear what sort of "local holidays", "gastronomic specialities", "folk art" or "handicrafts" they refer to when expressing their opinion. Finally, whether consciously or not, through vague words (e.g. and "customs", "traditions", "traditional", "specific", "specialities"), some representatives of the local authorities placed the responsibility of identifying and selecting appropriate elements on those directly involved into the territorial branding, not precisely explaining or, at least, exemplifying their understanding of these terms.

As with most studies, the design of the current study is subject to limitations. Essentially, the main constraint concerns the socio-demographic characteristics of the interviewed representatives of the local authorities. Undoubtedly, relevant biographical information related to age, origin, education level could have provided further explanations regarding their more or less detailed answers, perceptions, awareness of tourist potential, local knowledge and attitudes towards territorial identity elements pertinent enough to be used in the branding process within a well-defined area. 


\section{CONCLUSIONS}

The branding process is a complex process which should rely on elements which are easy to identify and differentiate from competitors. In the context of tourist destinations, this is where, the territorial identity intervenes in order to help capture the essence and provide the motivation for visiting it. Whether cognitive or affective, natural or cultural, the features for each area to focus on should be the irreproducible ones and, in order to find them, both research and strategic thinking are required. If the investigation could be efficiently performed by theoreticians, marketing experts, branding experts, who do not need to be insiders in order to critically review different sources of information, proposals, development theories and strategies, in the decision making process, the consultation and active implication of the locals (i.e. local authorities, direct beneficiaries and other interested parties) rather that outsiders is crucially important.

As this study has shown, as long as the positive impacts of tourism are being recognized by local authorities, it is only a matter of perspective to what extent specific examples of nature-based, man-made tourist attractions, cultural assets or general elements with symbolic value could become key factors within the brand image of any commune, with proper involvement and design. By combining all tangible and intangible elements of territorial identity, not only an adequate tourist product would emerge, but also a brand image capable of influencing the tourists' future intentions in terms of visiting the area and thus, through tourism activities, contributing to its economic development.

\section{REFERENCES}

ALAOUI, Y. \& ABBA, R. (2019). The R(evolution) of Territorial Marketing: Towards an Identity Marketing. Journal of Marketing Research and Case Studies, vol. 2019, Article ID 944163. DOI: 10.5171/2019.944163

APETREI, M. \& SURDU, I. (2017). Patrimoniul natural montan: Fundamentul diversităţii culturale şi a identităţii comunităţilor montane [The Natural Heritage of the Mountains: The Basis of Cultural Diversity and of the Identity of Mountain Communities]. Revista de Montanologie, 7, 153-162. Retrieved 10 April 2020, from http://www.ce-mont.ro/media/attachments/2018/12/03/patrimoniul-natural-montan-fundamentuldiversitii-culturale-i-a-identitii-comunitilor-montane.pdf

BÂCA, I. (2014). Brandul turistic al localităţilor de pe Valea Bârgăului [The Touristic Brand of the Settlements on the Bârgău Valley]. Anuarul Bârgăuan, 4(1). Retrieved 12 April 2020, from https://www.academia.edu/6236243/BRANDUL_TURISTIC_AL_LOCALIT\%C4\%82\%C8\%9AILOR_DE_PE_VALE A_B\%C3\%82RG\%C4\%82ULUI_loan_B\%C3\%A2ca_Universitatea_Babe\%C8\%99-Bolyai_ClujNapoca_Facultatea_de_Geografie

BAKER, M.J. \& CAMERON, E. (2008). Critical Success Factors in Destination Marketing. Tourism and Hospitality Research, 8(2), 79-97.

BALOGLU, S. \& MCCLEARY, K. (1999). A Model of Destination Image Formation. Annals of Tourism Research, 26(4), 868-897.

BANINI, T. (2017). Proposing a Theoretical Framework for Local Territorial Identities: Concepts, Questions and Pitfalls. Territorial Identity and Development, 2(2), 16-23.

BESSIÈRE, J. (1998). Local Development and Heritage: Traditional Food and Cuisine as Tourist Attractions in Rural Areas. Sociologia Ruralis, 38(1), 21-34.

BIRKNER, Z., MÁHR, T., \& RODEK BERKES, N. (2018). Settlement-territorial Identity. Proceedings of the Entrenova Conference (pp. 349-355), 6-8 September, Split, Croatia. 
BLAIN, C., LEVY, S.E., \& RITCHIE, B. (2005). Destination Branding: Insights and Practices from Destination Management Organizations. Journal of Travel Research, 43, 328-338.

BRAMWELL, B. (2004). Mass Tourism, Diversification and Sustainability in Southern Europe's Coastal Regions. In B. Bramwell (ed.), Coastal Mass Tourism: Diversification and Sustainable Development in Southern Europe (pp. 1-31). Clevedon, UK: Channel View Publications.

BUHALIS, D. (2000). Marketing the Competitive Destination of the Future. Tourism Management, 21(1), 97-116.

CAPELLO, R. (2018). Interpreting and Understanding Territorial Identity. Regional Science Policy, 11, 141-158.

CARNEIRO, M.J., LIMA, J., \& SILVA, A.L. (2015). Landscape and the Rural Tourism Experience: Identifying Key Elements, Addressing Potential and Implications for the Future. Journal of Sustainable Tourism, 23(8-9), 1217-1235.

CASTELS, M. (1997). The Power of Identity (2nd Edition). Oxford: Blackwell.

CHAPERON, S. \& BRAMWELL, B. (2013). Dependency and Agency in Peripheral Tourism Development. Annals of Tourism Research, 40, 132-154.

CHARTERS, S. \& SPIELMANN, N. (2014). Characteristics of Strong Territorial Brands: The Case of Champagne. Journal of Business Research, 67, 1461-1467.

COMMISSION EUROPEÈNE (1994). Valeur ajonté et ingénierie du développement local. Luxembourg: Office des Publications Officiele des Communautés Europennes.

CROMPTON, J.L. (1979). An Assessment of the Image of Mexico as a Vacation Destination and the Influence of Geographical Location upon That Image. Journal of Travel Research, 17(1), 18-23.

DJANKOV, T., KRASTEV, V., \& YANCHEVA, K. (2018). Evaluation of Brand Identity in Bulgaria as a Tourist Destination. Tourism, 66(1), 19-34.

DREDGE, D. \& JENKINS, J. (2003). Destination Place Identity and Regional Tourism Policy. Tourism Geographies, 5(4), 383-407.

EGRESI, I. (2002). Analysis of Agritourism Development in the New River Basin, North Carolina. Master's Thesis, Department of Geography and Planning, Appalachian State University, Boone, North Carolina, USA.

EGRESI, I. (2016b). Alternative Tourism: Definition and Characteristics. In I. Egresi (ed.), Alternative Tourism in Turkey: Role, Potential Development and Sustainability (pp. 57-69). Cham, Switzerland: Springer International.

EGRESI, I. (ed.) (2016a). Alternative Tourism in Turkey: Role, Potential Development and Sustainability. Cham, Switzerland: Springer International.

EUROPEAN COMMISSION (2011). Overview of the EU Rural Development Policy, 2007-2013. Retrieved 12 April 2020, from http://ec.europa.eu/agriculture/sites/agriculture/files/statistics/ruraldevelopmet2011/ch4.en.pdf

FILIMON, L., NEMEŞ, V., \& FILIMON, C. (2014). Local Development Model Based on Territorial Identity and Heritage: The Case of Romanian "Tara"/Lands. Revista Română de Geografie Politica, 16(2), 134-146.

FOLGADO-FERNÁNDEZ, J.A., NUNES, P., \& SECO-GONZÁLEZ, J. (2019). Tourist Events with Territorial Identity and Tourism Development: A Comparative Analysis between the Regions of Setubal (Portugal) and Extremadura (Spain). Journal of Tourism and Heritage Research, 2(2), 382-402.

GALLARZA, M.G., SAURA, I.G., \& GARCIA, H.C. (2002). Destination Image: Towards a Conceptual Framework. Annals of Tourism Research, 29(1), 56-78.

GAMAN, G., RĂCĂŞAN, B.S., \& POTRA A.C. (2017). Tourism and Polycentric Development in Urban and Rural Areas. Case Study: Triple-Pole Proposals in Bacău and Cluj Counties (Romania). GeoJournal of Tourism and Geosites, 19(1), 35-49.

GARTNER, W.C. (1993). Image Formation Process. Journal of Travel and Tourism Marketing, 2(2/3), 191-215.

Ghidul Primăriilor [Guide of the City Halls] (2020). Retrieved 13 March 2020, from https://www.ghidulprimariilor.ro/ro/businesses/city_hall_county/Cluj/13

GLIGOR, V., FILIP, S., DAVID, N. \& COCEAN, P. (2014). Potenţialul de dezvoltare agroturistică a microregiunii Tăşnad [Agro-tourism Development Potential of the Tăşnad Micro-region]. Geographia Napocensis, 8(2), 95-105.

HALL, S. (1996). Who Needs Identity? In S. Hall and P. du Gay (eds.), Questions of Cultural Identity (pp. 1-17). London: Sage. 
ILOVAN, O.-R., JORDAN, P., HAVADI-NAGY, K.X., \& ZAMETTER, T. (2016). Identity Matters for Development: Austrian and Romanian Experiences. Transylvanian Review, 25 (supplement no. 1), 261-276.

JÄNTTI, S., TIENSUU, H., \& RUSKO, R. (2013). Two Ways for Territorial Brand Promotion in Tourism Comparative Discourse Analysis: Lapland vs. Kuusamo and of South Tyrol vs. Italy. China-USA Business Review, 12(12), 1175-1194.

JEPSON, D. \& SHARPLEY, R. (2015). More than Sense of Place? Exploring the Emotional Dimension of Rural Tourism Experiences. Journal of Sustainable Tourism, 23(8-9), 1157-1178.

KAUPPILA, P., SAARINEN, J., \& LEINONEN, R. (2009). Sustainable Tourism Planning and Regional Development in the Peripheries: A Nordic View. Scandinavian Journal of Hospitality and Tourism, 9(4), 424-435.

KAVARATZIS, M. \& ASHWORTH, G.J. (2008). Place Marketing: How Did We Get Here and Where Are We Going? Journal of Place Management and Development, 1(2), 150-165.

KIM, D. \& PERDUE, R. (2011). The Influence of Image in Destination Attractiveness. Journal of Travel and Tourism Marketing, 28(3), 225-239.

KNEAFSEY, M. (1998). Tourism and Place Identity: A Case Study in Rural Ireland. Irish Geography, 31(2), 111-123.

KNEAFSEY, M. (2000). Tourism, Place Identities and Social Relations in the European Rural Peripheries. European Urban and Regional Studies, 7(1), 35-50.

KONECNIK, M. \& GO, F. (2008). Tourism Destination Brand Identity: The Case of Slovenia. Brand Management, 15(3), 177-189.

LANE, B. \& KASTENHOLZ, E. (2015). Rural Tourism: The Evolution of Practice and Research Approaches - Towards a New Generation Concept? Journal of Sustainable Tourism, 23, 8-9.

LEE, C.-K., KANG, S., REISINGER, Y., \& KIM, N. (2012). Incongruence in Destination Image: Central Asia Region. Tourism Geographies, 14(4), 599-624.

LEE, J., ARNASON, A., Nightingale, A., \& SHUCKSMITH, M. (2005). Networking Social Capital and Identities in European Rural Development. Sociologia Ruralis, 45(4), 269-283.

Lista comunelor cu punctajul acordat în funcție de potențialul turistic / Ordin 567/2008 [List of Communes with Scores according to Tourist Potentiall Order 567/2008] (2020). Retrieved 12 April 2020, from https://lege5.ro/Gratuit/geytonztha/lista-comunelor-cu-punctajul-acordat-in-functie-de-potentialul-turisticordin-567-2008?dp=gm4domrugm2tq

LITVIN, S.W. \& MOURI, N. (2009). A Comparative Study of the Use of Iconic vs. Generic Advertising Images for Destination Marketing. Journal of Travel Research, 48(2), 152-161.

LORENZINI, E., CALZATI, V., \& GIUDICI, P. (2011). Territorial Brands for Tourism Development: A Statistical Analysis on the Marche Region. Annals of Tourism Research, 38(2), 540-560.

MACKAY, J. \& FESENMAIER, R. (2000). An Exploration of Cross Cultural Destination Image Assessment. Journal of Travel Research, 38(4), 417-423.

MARSON, D. (2011). From Mass Tourism to Niche Tourism. In P. Robinson, S. Heitman, \& P. Dieke (eds.), Research Themes for Tourism (p. 1-11). Wallingford, UK: CABI.

MATEI-GHERMAN, C. (2010). Strategii de marketing în turismul rural [Marketing Strategies in Rural Tourism]. In I. Talabă, T. Păduraru, D. Ungureanu, \& R. Rachieru (eds.), Turismul Rural Românesc în Contextul Cercetări Dezvoltării Durabile: Actualitate şi Perspective (pp. 11-17). Iaşi, Romania: Tehnopres.

MAZILU, M. \& DUMITRESCU, D. (2012). Identity and Sustainable Development in Rural Tourism. Forum Geografic: Studii si Cercetări de Geografie şi Protecţia Mediului, 11 (Suppl. 1), 7-11.

MAZILU, M. (2014). Multiculturality and Tourist Identity Promotion in the Romanian Tourist Rural Space. International Journal for Responsible Tourism, 3(1), 22-43.

MEGRI, Z. \& BENCHERIF, F. (2014). The Effect of Territorial Marketing on City Image Valuation: An Exploratory Study in Algeria. International Journal of Marketing Studies, 6(4), 145-156.

MIDDLETON, A.C. (2011). City Branding and Inward Investments. In K. Dinnie (ed.), City Branding: Theory and Cases (pp. 15-26). London: Palgrave-Macmillan. 
OLIVEIRA, J., ROCA, Z., \& LEITÃO, N. (2010). Territorial Identity and Development: From Topophilia to Terraphilia. Land Use Policy, 27, 801-814.

ORTH, U.R., STÖCKL, A., VEALE, R., BROUARD, J., CAVICCHI, A., FARAONI, M., LARREINA, M., LECAT, B., OLSEN, J.E., RODRIGUEZ-SANTOS, C., SANTINI, C., \& WILSON, D. (2012). Using Attribution Theory to Explain Tourists' Attachment to Place-Based Brands. Journal of Business Research, 65(9), 1321-1327.

OU, Y. \& BEVILACQUA, C. (2017). From Territorial Identity to Territorial Branding: Tourism-Led Revitalization of Minor Historic Towns in Regio Calabria. 5th UNESCO UNTWIN Conference, Coimbra, Portugal.

PAASI, A. (2002). Bounded Spaces in the Mobile World: Deconstructing "Regional Identity". Tijdschrift voor Economische en Sociale Geografie, 93, 137-148.

PAASI, A. (2003). Regional Place: Regional Identity in Question. Progress in Human Geography, 27(4), 475-485.

PAASI, A. (2013). Regional Planning and the Mobilization of "Regional Identity": From Bounded Spaces to Relational Complexity. Regional Studies, 47(8), 1206-1219.

PAIVA, T., RAMOS, E., NEVES, J., RAPOSO, D., SILVA, R., CASTILHO, L., \& DESTERRO, T. (2019). Territorial Marketing as a Mean of Regional Valorization and Development Based on Religious Tourism: The Ordo Christi Case. 9th Advances in Hospitality and Tourism Marketing and Management Conference, Portsmouth, UL, 9-12 July.

PETREA, R., PETREA, D., OLĂU, P.E., \& FILIMON, L. (2013). Place Branding as Efficient Management Tool for Local Development. Transylvanian Review for Administrative Sciences, Special Issue, 124-140.

PIKE, S. \& RYAN, C. (2004). Destination Positioning Analysis through a Comparison of Cognitive, Affective and Conative Perceptions. Journal of Travel Research, 42, 333-342.

PLĂIAŞ, I., GHEREŞ, M. \& POP, I. (2010). Conturarea profilului consumatorului de turism rural: Primul pas spre dezvoltare durabilă [Sketching the Profile of the rural Tourism Consumer: First Step towards Sustainable Development]. In I. Talabă, T. Păduraru, D. Ungureanu, \& R. Rachieru (eds.), Turismul Rural Românesc în Contextul Cercetării Dezvoltării Durabile: Actualitate şi Perspective (pp. 59-66). laşi, Romania: Tehnopres.

PLUMED laSARTE, M., TENA PRAZUelO, V., \& ElBOJ SASO, C. (2011). The Use of Territorial Brands to Stand out as a Tourist Destination. Proceedings of the Conference "Territorial Brands for Tourist Destinations" (pp. 1-11), Rhodes, Greece. 11 Retrieved March 2020, from https://www.academia.edu/1039875/The_use_of_territorial_brands_to_stand_out_as_a_tourist_destination

POLLICE, F. (2003). The Role of Territorial Identity in Local Development Processes. Proceedings of the Conference: "The Cultural Turn in Geography - Part II: Landscape Construction and Cultural Identity" (pp. 107-117), 18-20 September, University of Trieste, Gorizia Campus (Italy). Retrieved 10 March 2020, from http://citeseerx.ist.psu.edu/viewdoc/download?doi=10.1.1.121.681\&rep=rep1\&type=pdf

RĂCĂŞAN, B.S. (2014). Types and Forms of Tourism Based on Natural and Anthropic Tourist Resources in Apuseni Mountains. Case Study: Rural Mountain Area of Cluj County. Geographica Timisiensis, XXIII(2), 5-26.

RĂCĂŞAN, B.S. (2015). Prospecting Event Tourism within the Rural-Mountain Area of Cluj County by Means of Online Promotion. Journal of Settlements and Spatial Planning, Special Issue, 4, 199-209.

RĂCĂŞAN, B.S. (2018). Turismul în spaţiul rural-montan şi de contact marginal din judeţul Cluj [Tourism within the Rural-Mountain and Marginal Contact Area in Cluj County]. Cluj-Napoca: Risoprint.

RĂCĂŞAN, B.S., \& GĂMAN, G. (2015). Tourist Image of Romania Reviewed by International Travel Guides. Comparative Study: English, French and German Editions. Journal of Tourism - Studies and Research in Tourism, 19, 60-73.

RĂVAR, A.S. (2012). Cultural Identity and Tourist Destination Development: A Case Study of the Land of Bârsa. Forum Geografic: Studii şi Cercetări de Geografie şi Protecţia Mediului, 11 (Suppl. 1), 44-51.

ROCA, Z. \& DE NAZARÉ OLIVEIRA-ROCA, M. (2007). Affirmation of Territorial Identity: A Development Policy Issue. Land Use Policy, 24, 434-442.

ROCA, Z., OLIVEIRA, J.A., \& DE NAZARÉ ROCA, M. (2016). Claiming Territorial Identity and Local Development: From Wishes to Deeds. In Z. Roca, P. Claval, \& J. Agnew (eds.), Landscapes, Identities and Development (pp. 319334). Farnham, UK: Ashgate.

SALVATORE, R., CHIODO, E., \& FANTINI, A. (2018). Tourism Transition in Peripheral Rural Areas: Theories, Issues and Strategies. Annals of Tourism Research, 68, 41-51. 
SIMON, C., HUIGEN, P., \& GROOTE, P. (2010). Analyzing Regional Identities in the Netherlands. Tijdschrift voor Economische en Sociale Geografie, 101, 409-421.

STANCIU, P. (2017). Analiza turismului cultural cu valenţe rustice din judeţul Botoşani în context transfrontalier [Analysis of Cultural Tourism with Rustic Valences in Botoşani County in a Trans-border Context]. In Culegere de Articole Selective ale Conferinţei Ştiinţifice Internaţionale "Competitivitatea şi Inovarea în Economia Cunoaşterii" (pp. 162-169), 22-23 September, Chişinău, Republic of Moldova (vol. 1).

STOFFELEN, A. \& VANNESTE, D. (2018). The Role of History and Identity Discourses in Cross-Border Tourism Destination Development: A Vogtland Case Study. Journal of Destination Marketing and Management, 8, 204-213.

STOFFELEN, A., GROOTE, P., MEJLES, E., \& WEITKAMP, G. (2019). Geoparks and Territorial Identity: A Study of the Spatial Affinity of Inhabitants with UNESCO Geopark De Houdsrug, The Netherlands. Applied Geography, 106, 1-10.

TIRADO-BALLESTEROS, J.G. \& HERNÁNDEZ-HERNÁDEZ, M. (2016). Assessing the Impact of EU Rural Development Programs on Tourism. Tourism Planning and Development, 14(2), 149-166.

ZBUCHEA, A. (2014). Territorial Marketing Based on Cultural Heritage. Management and Marketing, 12(2), 135-151. 